\title{
PENGARUH LATIHAN PLYOMETRIC SQUAT JUMP DAN HURDLE JUMP TERHADAP KETERAMPILAN BERMAIN SEPAK BOLA PADA PEMAIN PS UM
}

\author{
Akhmad Dani Setyawan \\ Fakultas Ilmu Keolahragaan \\ Universitas Negeri Malang \\ Jl. Semarang 5 Malang, 65145, Indonesia \\ Adsetiawan77@gmail.com \\ Mahmud Yunus \\ Fakultas Ilmu Keolahragaan \\ Universitas Negeri Malang \\ Jl. Semarang 5 Malang, 65145, Indonesia
}

\begin{abstract}
ABSTRAK
Penelitian ini bertujuan untuk mengetahui pengaruh latihan plyometric squat jump dan hurdle jump terhadap keterampilan jump heading pada pemain Persatuan Sepak Bola Universitas Negeri Malang. Penelitian ini merupakan penelitian pre-eksperimental, dengan menggunakan rancangan "the static Group Pretest-Posttest Design". Sampel dalam penelitian ini adalah pemain yang berlatih aktif sebagai pemain sepak bola Universitas Negeri Malang dengan menggunakan teknik purposive sampling dan memenuhi kriteria inklusi dan eksklusi yang telah ditetapkan oleh peneliti yaitu sebanyak 22 orang. Berdasarkan hasil analisis data, latihan squat jump dan hurdle jump memberikan pengaruh yang signifikan terhadap keterampilan jump heading dengan analisis 1) latihan plyometric squat jump $\left(t_{\text {hitung }}=12,450>t_{\text {tabel }}=1,812\right)$ dan besarnya perubahan tinggi loncatan tersebut dapat dilihat dari perbedaan nilai rata-rata pretest dan posttest yaitu sebesar $2,8 \mathrm{~cm}$. 2) latihan plyometric hurdle jump $\left(t_{\text {hitung }}=12,450>t_{\text {tabel }}=1,812\right)$ dan besarnya perubahan tinggi loncatan tersebut dapat dilihat dari perbedaan nilai rata-rata pretest dan posttest yaitu sebesar $5,6 \mathrm{~cm}$. Kesimpulan dari hasil penelitian ini adalah latihan plyometric squat jump dan hurdle jump dapat meningkatkan keterampilan jump heading. Dilihat hasil analisis yang dilakukan, latihan plyometric hurdle jump lebih meningkatkan keterampilan jump heading pada pemain Persatuan Sepak Bola Universitas Negeri Malang dibandingkan dengan latihan plyometric squat jump.
\end{abstract}

Kata Kunci: Plyometric Squat Jump, Plyometric Hurdle Jump, Jump Heading

\begin{tabular}{ll}
\hline Kualitas teknik dasar seperti & permainan sepak bola tidak lepas dari \\
passing, shooting, dribling, jump heading & faktor-faktor komponen fisik. Komponen \\
dalam sepak bola sangat penting untuk & fisik harus dilatih untuk meningkatkan \\
menunjang permainan. Jump heading & sebuah prestasi dalam bidang sepakbola \\
merupakan salah satu teknik yang & (Amiq, 2015:28). Komponen fisik yang \\
digunakan pada saat bola di udara Menurut & harus dilatih untuk meningkatkan prestasi \\
Budiwanto (2012:46) teknik dasar & adalah kelincahan, kekuatan, \\
merupakan "suatu proses melakukan & keseimbangan, fleksibilitas, daya tahan, \\
gerakan sederhana yang dilakukan dalam & dan power. power adalah komponen fisik \\
kondisi sederhana dan mudah". Kualitas & yang paling penting terhadap semua \\
keterampilan teknik dasar bermain dalam & pemain. Menurut Bompa dan Haff
\end{tabular}


(2009:233) "power merupakan hasil gabungan dari dua kemampuan yaitu kekuatan dan kecepatan maksimal dalam waktu yang singkat". Dimana power digunakan ketika menendang bola, menggiring bola, dan menyundul bola.

Menyundul bola salah satu teknik yang paling penting dalam permainan sepakbola (Sucipto, 2000). Menyundul bola dibutuhkan semua posisi dalam sepak bola, tidak hanya pemain depan saja, namun juga diperlukan pemain tengah dan pemain belakang, hingga penjaga gawang sekalipun untuk mengamankan pertahanan. Menyundul bola dapat dilakukan dengan cara sambil meloncat (jump heading) yaitu meloncat ke atas untuk menyundul bola. Dalam permainan sepak bola jump heading sangat diperlukan karena merupakan teknik bertahan dan menyerang. Cara yang paling baik untuk meningkatkan keterampilan dalam melakukan heading adalah dengan meningkatkan kemampuan meloncat (Mielke, 2007:53). Sedangkan menurut Sukatamsi (2001:171) untuk dapat meloncat lebih tinggi saat melakukan jump heading, seorang pemain sepakbola memerlukan daya ledak otot.

Loncatan yang tinggi bisa dicapai apabila power otot pada tungkai sudah terlatih. Power otot tungkai merupakan kemampuan dari seseorang dalam mengerahkan kekuatan yang dilakukan dengan kecepatan yang tinggi untuk mengatasi tahanan dan beban. Menurut Sulaiman (2018:124) menyatakan "kemampuan otot untuk mengerahkan kekuatan maksimal yang dilakukan dengan kecepatan tinggi disebut power" Berdasarkan kedua pendapat tersebut tinggi loncatan dapat tercapai dengan melakukan latihan yang berhubungan dengan power atau daya ledak.
Salah satu cara untuk meningkatkan daya ledak otot guna meningkatkan tinggi loncatan dapat dilakukan dengan latihan pliometrik. (Markovic, 2007:349) menyatakan "latihan pliometrik merupakan salah satu metode latihan yang bertujuan untuk meningkatkan loncatan dan kekuatan otot tungkai". Pliometrik merupakan latihan untuk meningkatkan daya ledak otot tungkai dengan menggunakan beban dalam atau beban sendiri. Latihan beban pliometrik merupakan latihan yang sumber bebannya berasal dari berat badan atlet itu sendiri. Hal ini sangat efisien dan efektif dalam pelatihan untuk meningkatkan daya ledak otot tungkai untuk meningkatkan tinggi loncatan. Menurut Sugiharto (2014:128) "Latihan pliometrik dapat memberikan kontribusi untuk meningkatkan kinerja vertical jump, percepatan, kekuatan kaki, power otot, dan meningkatkan join awereness". Salah satu bentuk latihan plyometric yang diterapkan pada model latihan untuk meningkatkan tinggi loncatan yaitu plyometric squat jump dan plyometric hurdle jump.

Penelitian Pliometrik squat jump dan hurdle jump ini dilakukan di PS UM (Persatuan Sepak Bola Universitas Negeri Malang). Aktivitas latihan di PS UM sudah bagus, namun kurang dalam aspek pelatihan power. Bisa dilihat dari hasil observasi yang telah peneliti lakukan, dimana belum adanya seorang pelatih disetiap jadwal latihan. Hal ini menjadi faktor kurang maksimalnya dalam meningkatkan keterampilan jump heading. Salah satu indikator utama dalam penelitian ini untuk meningkatkan tinggi loncatan dalam sepak bola adalah latihan Plyometric Squat Jump dan Hurdle Jump. Menurut (Rahayu, 2008:147) menyatakan "latihan plyometric bertujuan untuk 
menggerakkan bagian otot tungkai, karena otot tungkai sebagai pusat power gerakan vertical jump".

Berdasarkan uraian diatas, maka peneliti ingin melakukan penelitian dengan metode latihan Plyometric Squat Jump dan Hurdle Jump terhadap keterampilan bermain sepak bola pada Pemain PS UM yang bertujuan untuk meningkatkan tinggi loncatan, sehingga dapat memperbaiki kualitas teknik jump heading dan prestasi yang akan diraih di dunia keolahragaan terutama sepak bola.

\section{METODE}

Penelitian ini adalah penelitian Preexperimental, menurut (Sugiyono, 2011:74) dikatakan Pre-Eksperimental, karena desain ini belum merupakan eksperimen yang masih terdapat variabel luar yang ikut berpengaruh terhadap terbentuknya variabel dependen. Desain dalam penelitian ini menggunakan rancangan "the static Group PretestPosttest Design". Variabel bebas pada penelitian ini berupa latihan squat jump dan latihan hurdle hop. Sedangkan variabel terikat berupa tinggi loncatan pemain PS UM (Persatuan Sepak Bola Universitas Negeri Malang).

Dalam rancangan penelitian ini hal pertama yang dilakukan adalah melakukan pretest untuk mengetahui kemampuan awal dari perbedaan antara kelompok eksperimen pertama dan kelompok eksperimen kedua. Kemudian kelompok eksperimen pertama diberi perlakuan latihan squat jump $\left(\mathrm{X}_{1}\right)$, sedangkan kelompok eksperimen kedua diberi latihan hurdle jump $\left(\mathrm{X}_{2}\right)$. Setelah kedua kelompok eksperimen diberi perlakuan dalam jangka waktu 6 minggu maka, kedua kelompok eksperimen akan diberi posttest.
Populasi adalah seluruh subjek yang ingin diteliti oleh peneliti. Menurut (Sugiyono, 2011:56) "Populasi adalah wilayah generalisasi yang terdiri dari objek atau subjek yang mempunyai kualitas dan karakteristik tertentu yang ditetapkan oleh peneliti untuk dipelajari dan kemudian ditarik kesimpulannya". Populasi dalam penelitian ini adalah semua pemain Persatuan Sepak Bola Universitas Negeri Malang yang berjumlah 25 orang. Teknik pengambilan sampel yang digunakan adalah purposive sampling. Sampel dalam penelitian ini adalah pemain yang berlatih aktif sebagai pemain sepak bola Universitas Negeri Malang dan memenuhi kriteria inklusi dan eksklusi yang telah ditetapkan oleh peneliti yaitu 22 orang. Menggunakan rumus teknik slovin (Sugiyono, 2011:87) :

$$
n=\frac{\mathrm{N}}{1+\mathrm{N}(\mathrm{e})^{2}}=\frac{25}{1+25(0,05)^{2}}=\frac{25}{1,0625}=23,5
$$

Pembagian kelompok yaitu menggunakan teknik ordinal pairing matching (Hadi, 2004:512). Sebelumnya sampel diberi tes awal atau pretest untuk mengetahui kemampuan awal dan hasil tesnya diurutkan dari yang tertinggi. Teknik ordinal pairing matching merupakan pembagian dua kelompok yaitu kelompok pertama dan kedua. Nilai tertinggi dimulai dari kelompok pertama lalu pindah ke kelompok kedua dan selanjutnya dibalik, yaitu dimulai dari kelompok kedua lalu ke kelompok pertama. Teknik ini bertujuan untuk menyeimbangkan kedua kelompok sebelum diberi perlakuan(Sulaiman, 2018:125).

Penelitian ini dilaksanakan selama 6 minggu dengan frekuensi latihan 3 seminggu. Pada tanggal 11 November 
2019 - 20 Desember 2019, di lapangan sepak bola Universitas Negeri Malang.

Instrumen yang digunakan dalam penelitian ini adalah instrumen tes. Menurut Winarno (2013:71) instrumen penelitian adalah alat-alat yang digunakan untuk memperoleh atau mengumpulkan data dalam rangka memecahkan masalah penelitian atau untuk mencapai tujuan penelitian. Instrumen penelitian yang digunakan dalam penelitian ini dengan menggunakan metode pengukuran vertical jump. Untuk pengukuran tinggi loncatan atau kekuatan otot tungkai dapat menggunakan vertical power jump test (Alsyahbana, 2012:23).

\section{HASIL}

\section{Uji Normalitas}

Berikut ini hasil Uji normalitas disajikan dalam tabel 3 dan 4 sebagai berikut:

Tabel 3 Hasil Uji Normalitas (Shapiro-wilk) untuk Skor Pretest dan Posttest Kelompok Latihan Plyometric Squat Jump

\begin{tabular}{ccc}
\hline $\begin{array}{c}\text { Tes Vertical } \\
\text { Jump }\end{array}$ & Pretest & Posttest \\
\hline Shapiro-Wilk & 0,963 & 0,953 \\
\hline Signifikansi & 0,804 & 0,688 \\
\hline Keterangan & Normal & Normal \\
\hline
\end{tabular}

Tabel 4 Hasil Uji Normalitas (Shapiro-wilk) untuk Skor Pretest dan Posttest Kelompok Latihan Plyometric Hurdle Jump

\begin{tabular}{ccc}
\hline $\begin{array}{c}\text { Tes Vertical } \\
\text { Jump }\end{array}$ & Pretest & Posttest \\
\hline Shapiro-Wilk & 0,949 & 0,630 \\
\hline Signifikansi & 0,804 & 0,991 \\
\hline Keterangan & Normal & Normal \\
\hline
\end{tabular}

Berdasarkan hasil uji normalitas pada tabel di atas dapat diketahui bahwa untuk semua data pengamatan yang terdiri dari skor pretest dan posttest kelompok latihan plyometric squat jump dan hurdle jump memiliki nilai signifikansi $>\alpha=$ 0,05, sehingga dapat dinyatakan bahwa data yang digunakan dalam penelitian ini masuk dalam kategori normal.

\section{Uji Homogenitas}

Berikut ini hasil uji homogenitas untuk tes vertical jump kelompok latihan plyometric squat jump dan plyometric hurdle jump disajikan dalam tabel 5 sebagai berikut:

Tabel 5 Hasil Uji Homogenitas (Levene Test) untuk Skor Pretest dan Posttest Kelompok Latihan Plyometric Squat Jump dan Hurdle Jump

\begin{tabular}{cc}
\hline Data Tes & Pretest dan Posttest \\
\hline Levene Statistic & 0,051 \\
\hline Signifikansi & 0,985 \\
\hline Keterangan & Normal \\
\hline
\end{tabular}

Berdasarkan uji homogenitas pretest dan posttest kelompok latihan plyometric squat jump dan plyometric hurdle jump di atas didapatkan nilai signifikansi $>\alpha=0,05$, sehingga dapat disimpulkan bahwa ragam untuk kedua kelompok latihan plyometric squat jump dan plyometric hurdle jump masuk dalam kategori homogen atau sejenis

\section{Uji Hipotesis}

\section{Perbandingan Pretest dan Posttest} Tinggi Loncatan Kelompok Latihan

\section{Plyometric Squat Jump}

Uji-t digunakan untuk menguji hipotesis pertama yang berbunyi "Ada pengaruh latihan plyometric squat jump terhadap keterampilan jump heading pada pemain Persatuan Sepak Bola Universitas Negeri Malang". Berdasarkan hasil analisis diperoleh data sebagai berikut: 
Tabel 6 Uji t Hasil Pretest dan Posttest Tinggi Loncatan Kelompok Plyometric Squat Jump

\begin{tabular}{cccc}
\hline Jenis Data & t hitung & t tabel & Signifikansi \\
\hline $\begin{array}{c}\text { Pretest dan } \\
\text { Posttest }\end{array}$ & 12,450 & 1,812 & 0,000 \\
\hline
\end{tabular}

Dari hasil uji $\mathrm{t}$ dapat dilihat bahwa $\mathrm{t}$ hitung 12,450 dan $\mathrm{t}$ tabel 1,812 (df10) dengan nilai signifikansi sebesar 0,000. Oleh karena thitung 12,450 > t tabel 1,812 dan nilai signifikansi $0,000<0,05$, maka hasil ini menunjukkan terdapat perbedaan yang signifikan. Dengan demikian hipotesis alternatif (Ha) yang berbunyi "Ada pengaruh latihan plyometric squat jump terhadap keterampilan jump heading pada pemain sepak bola Universitas Negeri Malang", diterima. Artinya latihan squat jump memberikan pengaruh yang signifikan terhadap tinggi loncatan pada pemain Persatuan Sepak Bola Universitas Negeri Malang.

\section{Perbandingan Pretest dan Posttest}

\section{Tinggi Loncatan Kelompok Latihan}

\section{Plyometric Hurdle Jump}

Uji-t digunakan untuk menguji

hipotesis kedua yang berbunyi "Ada pengaruh latihan plyometric hurdle jump terhadap keterampilan jump heading pada pemain Persatuan Sepak Bola Universitas Negeri Malang”. Berdasarkan hasil analisis diperoleh data sebagai berikut:

Tabel 7 Uji t Hasil Pretest dan Posttest Tinggi Loncatan Kelompok Plyometric Hurdle Jump

\begin{tabular}{cccc}
\hline Jenis Data & $\mathbf{t ~ h i t u n g}$ & $\mathbf{t}$ tabel & Signifikansi \\
\hline $\begin{array}{c}\text { Pretest dan } \\
\text { Posttest }\end{array}$ & 12,450 & 1,812 & 0,000 \\
\hline
\end{tabular}

Dari hasil uji t dapat dilihat bahwa $\mathrm{t}$ hitung 12,450 dan $\mathrm{t}$ tabel 1,812 (df10) dengan nilai signifikansi sebesar 0,000 .
Oleh karena $\mathrm{t}$ hitung $12,450>\mathrm{t}$ tabel 1,812 dan nilai signifikansi $0,000<0,05$, maka hasil ini menunjukkan terdapat perbedaan yang signifikan. Dengan demikian hipotesis alternatif (Ha) yang berbunyi "Ada pengaruh latihan plyometric hurdle jump terhadap keterampilan jump heading pada pemain sepak bola Universitas Negeri Malang", diterima. Artinya latihan hurdle jump memberikan pengaruh yang signifikan terhadap tinggi loncatan pada pemain Persatuan Sepak Bola Universitas Negeri Malang.

Perbandingan Tinggi Loncatan Kelompok Plyometric Squat Jump dan Hurdle Jump

Pengujian dengan menggunakan One-Way ANOVA digunakan untuk mengetahui perbandingan antara kedua model latihan plyometric squat jump dan hurdle jump yang diterapkan untuk meningkatkan keterampilan jump heading. Berdasarkan hasil analisis diperoleh data sebagai berikut.

\section{Tabel 8 Uji Perbedaan Kelompok} Plyometric Squat Jump dan Hurdle Jump (One-Way ANOVA)

\begin{tabular}{ccc}
\hline Kelompok & Rata-rata & Selisih Mean \\
\hline $\begin{array}{c}\text { Pretest-Posttest } \\
\text { Squat Jump }\end{array}$ & 2,8 & \\
\hline $\begin{array}{c}\text { Pretest-Posttest } \\
\text { Squat Jump }\end{array}$ & 5,6 & 2,8 \\
\hline
\end{tabular}

Dari hasil uji t dapat dilihat bahwa f hitung 2,997 dan $\mathrm{f}$ tabel 2,839 dengan nilai signifikansi $\mathrm{p}$ sebesar 0,042 . Oleh karena $\mathrm{t}$ hitung 2,997>t tabel 2,839 dan nilai signifikansi $0,042<0,05$ maka hasil ini menunjukkan terdapat perbedaan yang signifikan. Dengan demikian hipotesis alternatif (Ha) yang berbunyi "Ada perbedaan pengaruh antara latihan plyometric squat jump dan hurdle jump terhadap keterampilan jump heading pada 
pemain Persatuan Sepak Bola Universitas Negeri Malang", diterima. Dapat dilihat dari rata-rata pretest-posttest squat jump sebesar $2,8 \mathrm{~cm}$ dan rata-rata pretestposttest hurdle jump sebesar $5,6 \mathrm{~cm}$.

\section{PEMBAHASAN}

\section{Pengaruh Latihan Plyometric Squat Jump dan Hurdle Jump Terhadap Tinggi Loncatan}

Dalam permainan sepak bola tinggi loncatan berperan sangat penting untuk menunjang salah satu teknik dasar yaitu teknik jump heading. Salah satu cara untuk menyempurnakan teknik jump heading adalah dengan memperbaiki tinggi loncatan. Salah satu faktor yang mempengaruhi tinggi loncatan yaitu power otot tungkai. Untuk meningkatkan tinggi loncatan dapat dilakukan dengan latihan yang berhubungan dengan power, salah satunya latihan plyometric. Bentuk dari latihan plyometric yang digunakan dalam penelitian ini yaitu latihan squat jump dan hurdle jump.

Plyometric squat jump adalah salah satu bentuk latihan dengan cara dua tangan dibelakang kepala, kemudian meloncat jongkok berdiri (Santosa, 2015:2). Sedangkan, hurdle jump adalah bentuk latihan dengan cara berdiri pada dua kaki selebar bahu, kemudian melakukan loncatan ke depan dengan melewati beberapa rintangan dengan kaki ditekuk dan mendarat pada dua kaki (Sugiharto, 2014:134). Gerakan kedua latihan ini terfokus pada anggota gerak bagian bawah yang dimana nanti akan merangsang otot yang ada di tungkai.

Dalam gerakan plyometric terdapat tiga fase yaitu fase eksentrik, fase amortisasi, dan fase konsentrik. Pada saat melakukan gerakan squat jump dan hurdle jump, dimana otot akan berkontraksi secara eksentrik dan konsentik. Hal ini akan menyebabkan otot pada atlet menjadi lebih kuat. Menurut Wang (2016:551) mengatakan "atlet mengulangi siklus tiga bagian ini secepat mungkin, dengan tujuan untuk mengurangi jumlah waktu di antara gerakan eksentrik dan konsentris. Pengurangan waktu di antara gerakan eksentrik dan konsentris mendorong atlet untuk menjadi lebih cepat dan lebih kuat".

Beban latihan dalam penelitian ini juga tidak semena-mena diberikan pada pemain sepak bola Universitas Negeri Malang (PS UM). Peningkatan beban dapat dilakukan dengan cara peningkatan intensitas latihan, frekuensi latihan, dan lama latihan. Intensitas latihan dalam penelitian ini dimulai dari intensitas rendah pada minggu ke-1, lalu meningkat pada intensitas sedang pada minggu ke-3, dan akan meningkat lagi pada intensitas tinggi pada minggu ke-4. Hal ini agar tubuh merasakan atau beradaptasi dengan latihan yang diberikan selama penelitian. Menurut Sugiharto (2014:37) menyatakan"beban latihan harus dapat direspon untuk melakukan adaptasi dengan baik oleh tubuh, karena beban latihan yang melebihi nilai ambang kemampuan adaptasi menimbulkan stressor bagi tubuh". Sedangkan menurut Carvalho A (2014:125) menyatakan bahwa"adaptasi dari latihan kekuatan akan berdampak pada peningkatan kekuatan otot dan pengembangan kapasitas produksi energi untuk perbaikan kebutuhan energi.

Latihan yang diterapkan dengan teratur berdasarkan program latihan yang telah dirancang dengan baik yaitu latihan plyometric squat jump dan hurdle jump yang diberikan pada pemain Persatuan Sepak Bola Universitas Negeri Malang 
dapat direspon dengan baik dan mengalami peningkatan dalam tinggi loncatan. Hal ini sesuai dengan rekomendasi dari hasil penelitian yang dilakukan oleh (Markovic, 2007) yaitu dimana latihan plyometric dapat memberikan signifikansi statistik dan peningkatan yang relevan dalam peningkatan tinggi loncatan rata-rata $4,7 \%$.

\section{Pengaruh Latihan Plyometric Squat} Jump Terhadap Peningkatan Tinggi Loncatan

Latihan squat jump adalah salah satu bentuk latihan plyometric. Untuk melakukan gerakan squat jump yaitu dimulai posisi tubuh sedikit jongkok dan posisi kaki dibuka selebar bahu lalu loncat vertikal sekuat mungkin, usahakan posisi kaki lurus ketika melayang di udara dan saat mendarat lakukan seperti posisi awal. Latihan ini dimulai dengan 4 set dan 10 repetisi pada kisaran intensitas rendah pada minggu pertama. Setiap minggunya akan ada peningkatan volume latihan meliputi set dan repetisi.

Hasil analisis menunjukkan bahwa terdapat peningkatan tinggi loncatan pemain sepak bola Universitas Negeri Malang (PS UM) setelah latihan plyometric squat jump. Hal ini ditunjukkan nilai $\mathrm{t}$ hitung $12,450>\mathrm{t}$ tabel 1,812 dan nilai signifikansi $0,000<0,05$, maka hasil ini menunjukkan terdapat perbedaan yang signifikan. Artinya latihan plyometric squat jump memberikan dampak terhadap peningkatan tinggi loncatan. Dari data pretest memiliki rata-rata $50,18 \mathrm{~cm}$, selanjutnya pada saat posttest rata-rata mencapai $53 \mathrm{~cm}$. Besarnya penigkatan tinggi loncatan bisa dilihat dari perbedaan rata-rata pretest dan posttest yaitu sebesar $2,8 \mathrm{~cm}$. Latihan squat jump ini akan merangsang otot betis dan paha. Menurut Hansen (2017:33) otot yang terlibat saat melakukan gerakan squat jump yaitu "gluteus maximus, gluteus medius, quadriceps (rectus femoris, vastus lateralis, vastus intermedius, vastus medialis), hamstrings (biceps femoris, semitendinosus, semimembranosus).

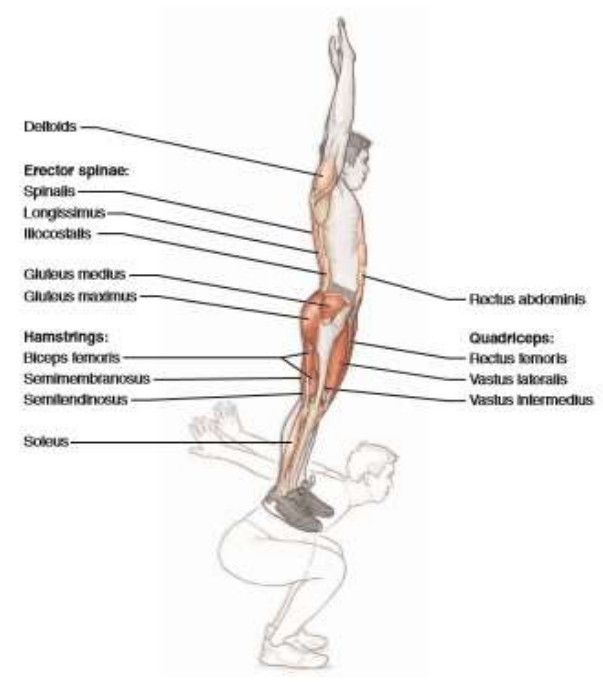

Gambar 1. Otot pada Gerakan Squat Jump Sumber: Hansen (2017:32)

\section{Pengaruh Latihan Plyometric Hurdle Jump Terhadap Peningkatan Tinggi Loncatan}

Latihan hurdle jump adalah salah satu bentuk latihan plyometric. Untuk melakukan gerakan hurdle jump yaitu dimulai berdiri dengan kaki selebar bahu, dan kemudian melakukan loncatan ke arah depan dengan melewati penghalang, pada saat meloncat posisi kaki ditekuk dan mendarat pada dua kaki. Latihan ini dimulai dengan 4 set dan 10 repetisi pada kisaran intensitas rendah pada minggu pertama. Setiap minggunya akan ada peningkatan volume latihan meliputi set dan repetisi.

Hasil analisis menunjukkan bahwa terdapat peningkatan tinggi loncatan pemain sepak bola Universitas Negeri Malang (PS UM) setelah latihan plyometric hurdle jump. Hal ini ditunjukkan nilai $\mathrm{t}$ hitung 12,450 > t tabel 
1,812, dan nilai signifikansi $0,000<0,05$, maka hasil ini menunjukkan terdapat perbedaan yang signifikan. Artinya latihan plyometric hurdle jump memberikan dampak terhadap peningkatan tinggi loncatan. Dari data pretest memiliki ratarata $50,18 \mathrm{~cm}$, selanjutnya pada saat posttest rata-rata mencapai $55,82 \mathrm{~cm}$. Besarnya penigkatan tinggi loncatan bisa dilihat dari perbedaan rata-rata pretest dan posttest yaitu sebesar $5,6 \mathrm{~cm}$. Latihan hurdle jump ini akan merangsang otot betis dan paha. Menurut Hansen (2017:98) otot yang terlibat saat melakukan gerakan hurdle jump yaitu "gluteus maximus, gluteus medius, quadriceps(rectus femoris, vastus lateralis, vastus intermedius, vastus medialis), soleus, gastrocnemius".

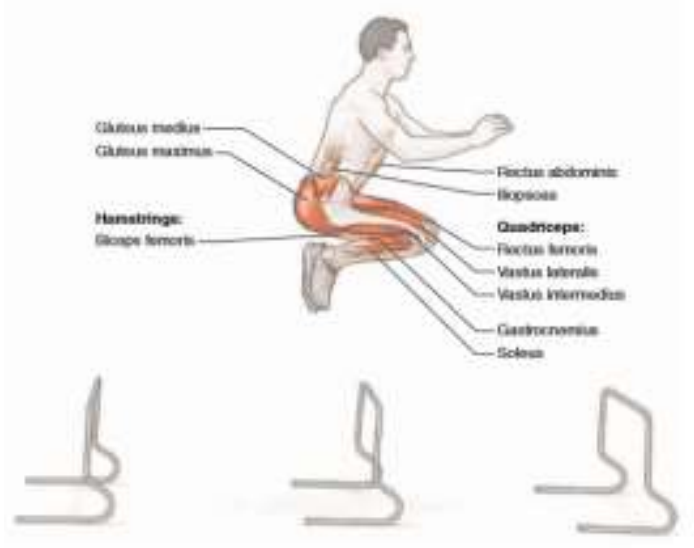

Gambar 2 Otot pada Gerakan Hurdle Jump Sumber: Hansen (2017:98)

Perbedaan Plyometric Squat Jump dan Hurdle Jump Terhadap Peningkatan Tinggi Loncatan

Hasil analisis menunjukkan terdapat perbedaan pengaruh antara squat jump dan hurdle jump. Berdasarkan data yang diperoleh dari rata-rata pretestposttest squat jump sebesar $2,8 \mathrm{~cm}$ dan rata-rata pretest-posttest hurdle jump sebesar 5,6 cm. Dimana latihan hurdle jump lebih efektif dari pada latihan squat jump untiuk meningkatkan tinggi loncatan pada pemain sepak bola Universitas Negeri Malang.

Latihan hurdle jump gerakannya meloncat ke depan dengan melewati beberapa rintangan. Berbeda dengan latihan squat jump gerakannya hanya meloncat ke atas saja. Latihan plyometric squat jump dan hurdle jump ini bertujuan untuk melatih otot pada anggota gerak bawah atau power pada otot tungkai. Pengertian yang membedakan dari kedua latihan ini adalah hurdle jump diawali dengan kotraksi eksentrik lalu dilanjutkan kontraksi konsentrik, sedangkan squat jump diawali dengan kontraksi konsentrik lalu dilanjutkan kontraksi eksentrik. Walaupun gerakan squat jump mirip dengan gerakan pada saat meloncat pada saat melakukan teknik heading, namun latihan hurdle jump memiliki intensitas gerakan yang lebih sulit dibandingkan dengan squat jump. Berikut gambaran intensitas latihan plyometric:

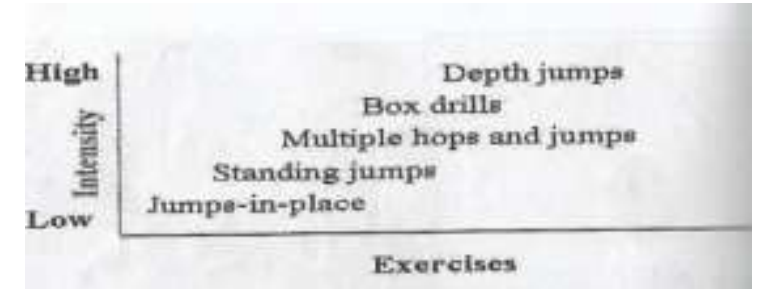

Gambar 3 Intensitas Plyometric Sumber:Sugiharto(2014:128)

Dimana latihan Squat Jump masuk dalam intensitas rendah dan hurdle jump berada di intensitas sedang. Hal ini sangat berpengaruh terhadap peningkatan tinggi loncatan.

\section{KESIMPULAN}

Berdasarkan penelitian yang sudah dilakukan 6 minggu tentang pengaruh latihan plyometric squat jump dan hurdle jump terhadap keterampilan jump heading pada pemain Persatuan Sepak Bola Universitas Negeri Malang. Dilihat dari 
hasil analisis data, deskpripsi, pengujian hasil penelitian, dan pembahasan dapat diambil kesimpulan terdapat pengaruh latihan plyometric squat jump dan hurdle jump terhadap keterampilan jump heading pada pemain Persatuan Sepak Bola Universitas Negeri Malang dan terdapat perbedaan antara latihan plyometric squat jump dan hurdle jump. Dimana latihan plyometric hurdle jump lebih efektif untuk meningkatkan tinggi loncatan.

\section{SARAN}

1) Bagi para pelatih atau pemain diharapkan dapat menerapkan latihan plyometric squat jump dan hurdle jump sebagai variasi latihan untuk meningkatkan keterampilan jump heading pada pemain sepak bola. 2) Para pelatih pemain sepak bola pada umumnya supaya lebuh kreatif dalam menciptakan model-model dan variasi latihan, agar tidak tmembosankan bagi pemain. 3) Peneliti selanjutnya diharapkan dapat menjadikan penelitian ini sebagai rujukan ataupun dapat digunakan sebagai penelitian lanjutan dengan penambahan variabel-variabel lain dan jumlah subjek yang lebih banyak. 4) Bagi Fakultas Ilmu Keolahragaan Universitas Negeri Malang dapat dijadikan sebagai pustaka dalam membantu mengembangkan keilmuan dibidang olahraga pada cabang olahraga sepak bola maupun cabang olahraga lainnya.

\section{DAFTAR RUJUKAN}

Alsyahbana, M. 2012. Profil Tinggi Badan, Daya Ledak (Power) Otot Tungkai, Kelincahan (Agility), dan Daya Tahan (Endurance) Atlet Bulu Tangkis. Surabaya: Fakultas Ilmu Keolahragaan Universitas Negeri Surabaya.

Amiq, F. 2016. Sepak Bola (Sejarah Perkembangan, eknik Dasar,
Persiapan Kondisi Fisik, Peraturan Permainan dan Strategi Bermain). Malang: Universitas Negeri Malang

Anwer, U. \& Nuhmani, S. 2015. Lower quarter plyometric for soccer players. Saudi Journal of Sports Medicine 15(1), 20-25.

Davies, G., Bryan L. Riemann., Robert Manske. 2015. Current Concepts Of Plyometric Exercise. The International Journal of Sports Physical Therapy 10(6). ResearchGate.

Derek Hansen \& Steve Kennelly. 2017. Plyometric ANATOMY (Your Illustrated Guide to Exsplosive Power. Canada: Human Kinetics.

Dwi Rosella Komala Sari \& Umi Budi Rahayu. 2008. Pengaruh Latihan Plyometrics Depth Jump Terhadap Peningkatan Vertical Jump pada Atlet Bola Voli Putri Yunior di Klub Vita Surakarta. Jurnal Fisioterapi Indonusa. Vol 8 (2). Halaman 145-148.

Ebben, W.P., Timothy J. Suchomel, and Luke R. Garceau. 2014. The Effect Of Plyometric Training Volume On Jumping Performance. ResearchGate..

Hadi, S. 2004. Metodologi Research. Yogyakarta: ANDI.

Jennifer L, Hunnicutt, Craig L, Elder, J. Jay Dawes and Amanda J, Sinclair Elder. 2016. The Effect Of a Plyometric Training Program On Jump Performance In Collegiate Fugure Skaters: A Pilot Study. USA: Universitas Of Soouth Carolina.

Markovic, G. 2007. Does Plyometric Training Improve Vertical Jump 
Height? A Meta-analytical review. Br J Sport Med 41: 349-335.

Mielke, D. 2007. Dasar-Dasar Sepak Bola. Bandung: PT Intan Sejati.

Ozmen, T., Mert Aydogmus . 2017. Effect Of Plyometric Training On Jumping Performance And Agility In Adolescent Badminton Players. Turkish Journal of Sport and Exercise 19(2).

Patel, N.N. 2014. Plyometric Training: A Review Article. Int J Cur Res Rev 6(15).

Rajan, S.R, Pushparajan, A. Ph.D. 2010. Effects Of Plyometric Training On The Development The Vertical Jump In Volleyball Players. Journal of Physical Education and Sport. 28(3).

Ramirez-Campillo, R., dkk. . 2015. Effect Of Progressive Volume-Based Overload During Plyometric Training On Explosive And Endurance Performance In Young Soccer Players. Journal of Strength and Conditioning Research 9(7).

Rosmawati. 2007. Pengaruh Latihan Beban Pliometrik dan Konvensional terhadap Daya Ledak Otot Tungkai dalam Jurnal Skolar Vol.8, No.2, Desember 2007.

Stojanović, N., Nikodije Jovanović., Toplica Stojanović. 2012. The Effects Of Plyometric Training On The Development Of The Jumping Agility In Volleyball Players. Physical Education and Sport Vol. 10, No 1, 2012, pp. 59 - 73

Sucipto, dkk. 2000. "Sepak Bola". Departemen Pendidikan dan Kebudayaan.
Sugiharto. 2014. Fisiologi Olahraga. Malang: Universitas Negeri Malang.

Sugiyono. 2011. Metodologi Penelitian Pendidikan. Bandung: CV Alfabeta.

Sukadiyanto \& Dangsina Muluk. 2013. Melatih Fisik. Bandung: PT. Lubug Agung.

Sukatamsi. 2001. Permainan Besar I Sepak Bola. Jakarta: Universitas Terbuka.

Sulaiman, Raharjo, A., Abidin W.Z. 2018. Effect of Plyometric Tuck Jump and Lateral Hurdle Jump on the Ability of Takraw Male Athletes to Do Smash Kedeng. Advances in Health Science Research, Volume 12.

Turner, A.N \& Jeffreys. 2010. The StretchShortening Cycle: Proposed Mechanisms and Methods for Enhancement. Strength and Conditioning Journal 32(4).

Vassil, K., Bazanovk, B. 2012. The Effect Of Plyometric Training Program On Young Volleyball Players In Their Usual Training Period. Journal of Human Sport and Exercise, vol. 7(1), pp. S34-S40. Universidad de Alicante Alicante, España.

Vladan Millic, Dragan Nejic, Radomir Kostic. 2008. The Effect Of Plyometric Training On The Explosive Stregth Of Leg Muscles Of Volleyball Players On Single Foot and Two-foot Take of Jump. Serbian: Universitas Of Nis.

Wang, Y \& Na Zhang. 2016. Effects of plyometric training on soccer players (Review). Experimental And Therapeutic Medicine 12:550554. 
Winarno, M.E. 2013. Metodologi Penelitian dalam Pendidikan Jasmani. Malang: Universitas Negeri Malang Fakultas Ilmu Pendidikan.
Yunus, M. 2013. Dasar-dasar Permainan Sepak Bola. Malang: Universitas Negeri Malang. 